\title{
Crowd funding: financial service for unserved crowds in Indonesia
}

\author{
Taofik Hidajat $^{1, *}$, Ina Primiana ${ }^{1}$, Sulaeman Rahman Nidar ${ }^{1}$, Erie Febrian $^{1}$ \\ ${ }^{1}$ Padjadjaran University, Indonesia \\ *Corresponding author: inidotcom@yahoo.com
}

\section{ABSTRACT}

The low level of financial inclusion or limited access to capital is one of most significant constraint faced by micro, small and medium-sized enterprises (SMEs) in Indonesia. To solve the problem, this study proposed a model of financing for SMEs through crowd funding mechanism that is currently emerging as a solution to solve the problem of funding sources, especially to finance new projects. From the study conducted with qualitative methods, it was concluded that the appropriate crowd funding model was the investment model by utilizing the principle of profit sharing such as mudharabah.

The principle of sharing is considered as the fairer and precise business management cooperation mechanism if it is compared with conventional contract. Crowd funding business model consists of three main actors, namely SMEs as those in need of capital, crowd funders as the party who provides the capital, and crowd funding operator as the party who brings together and facilitates SMEs with crowd funders. Another supporting factors are website with crowd funding platform and bank as payment gateway.

Keyword: crowd funding; Indonesia; SMES; financial inclusion; mudharabah

\section{INTRODUCTION}

Micro, small and medium-sized enterprises (SMEs) are the parts of economic sector which are not only able to give positive contribution to the national economy but they are also immune to the crisis. Due to the good condition of SMEs will be able to give a positive impact not only on the business entities, but also to the national economy (Prasetyo, 2008), then efforts urged to be done to give them better condition is a must. The present business world is facing many challenges.

But in the real fact, the efforts to improve performance of SMEs are still constrained by many factors. One of them is the lack of capital (Shaban, Duygun, Anwar, \& Akbar, 2014). It is a significant but also classical problem. Problem of financial inclusion faced by SMEs are difficulty and limited access to get funding fascility. They are caused by demand and supply factors.

From the demand side, the problem may occur because of the low level of financial literacy of the people (Hidajat, 2015). Financial literacy is a predictor of financial services demand (Cole, Sampson, \& Zia, 2009). In other words, the people with low level of financial literacy will be correlated with low financial inclusion and vice versa. With financial literacy level of only $20 \%$ and the level is much lower than the Philippines (27\%), Malaysia (66\%), Thailand (73\%), and Singapore (98\%) (DEFINIT, 2013), it can be concluded that financial inclusion of Indonesian people belongs to the lower levels. This conclusion was consistent with the survey result of World Bank in 2010, which suggested that only $49 \%$ of Indonesian households that had access to formal financial institutions, $52 \%$ of Indonesian people lived in rural areas, and $60 \%$ of them did not have access to formal financial services. The other determinant factors were cultural factors such as borrowing money informally habit, younger age of business that were not bankable, bad financial administration, and so on.

From the supply side, the low level of financial inclusion is caused by a mismatch of credit offered of the type of business, the complexity of administrative procedures, too thight prudential principle, limited range of services, and so on. In the fact, Indonesia is a global leader in microfinance ((Rosengard \& Prasetyantoko, 2011)). This condition is a paradox because on the 
one hand, SMEs need funding fascility but on the other hand, the banks with excessive funds are constrained by many requirements that they can not give loans.

Some models have been formulated to overcome financial inclusion problems as well as a no-frills accounts banking, branchless banking (business correspondent model), bank without a bank, micro lending, and so on (Bansal, 2012). The strategy has been applied in South Africa (no-frills banking), Brazil (branchless banking), Kenya (bank without a bank), and Mexico (micro credit) (Gwalani \& Parkhi, 2014). In Indonesia, various efforts to promote financial inclusion have been done although they are constrained by geographical factors and changes in regulations as proven by the success of some programs such as TabunganKu, Kredit Usaha Rakyat, mobile banking and microfinance (Rillo, 2014).

In such situations, financing effort through the mechanism of crowd sourcing or crowd funding is raised as a solution to overcome the problem of funding sources, especially to fund start-up project (Tomczak \& Brem, 2013). Crowdfunding is a form of digital economic activity in which a large number of people (the crowd) is collecting and distributing funds through an online platform for people and institutions (Langley, 2016). Crowdfunding term was popularized by a British rock band, Marillion. The band raised funds online to finance its tour in the United States from their fans in 1997.

The model of financing through crowd funding is relatively new. However, it is able to give significant contribution for the business. Apparently, crowd funding is a new threat forventure capital and angel investors (Vulkan, Åstebro, \& Sierra, 2016). Some of the benefits that can be gained from the implementation of this model is that it can be an alternative funding for SMEs to get venture capital financing in a cheaper, faster, broad, and fair way, and so improving inclusion or SME access to capital resources more easily without the constraints of time and place. It is also an investment alternative for investors (crowdfunder) as well as investment diversification tools for investors to put their funds in some SMEs. Roig Hernando (2016) explained that crowd funding was able to optimize portfolios for both individual and institutional investors.
According to Prive (2012), some benefits of crowd funding for the parties who need capital are providing access to capital sources, reducing risk, being marketing media, convincing the concept of business owned to the other parties, receiving criticism and input from other parties, being promoting media of business to prospective financiers, creating an easier procedure than traditional financing, being free public relations media, and opportunities for pre-selling without cost.

According to Harrison (2013), there were five models of crowd funding. They were donation, reward, pre-purchase, lending (peer-to-peer) and equity. Model of donation will not give contributors anything because it was closer to help charity or social activities. Model of reward will give contributors some forms. Pre-purchase model is almost the same as the model of reward, but it gives contributors the products financed by the project. Lending (peer-to-peer) will provide income for contributors because this model is a business loan. Equity model will share the business or benefits to contributors because of its nature as capital investment. In the practice, there are some variations in this model (Vasileiadou, Huijben, \& Raven, 2016).

Based on review of characteristics of each model, crowd funding can be a solution to overcome the problem of financing faced by SMEs. Nowadays, we can find some crowd funding sites such as Gofundme, Kickstarter, Indiegogo, Teespring, Patreon, YouCaring, et cetera. In Indonesia, there are KitaBisa.com, Wujudkan.com, Patungan.net, Gagas.web.id, Crowdo.com, and so on. Although not all projects funded were succesful, but there were some success stories of projects funded through crowd funding. For example, some of the successful projects and the amount of funds obtained were Star Citizen video game, Pebble Time, product design of Coolest Cooler, Ubuntu Edge smartphone, Flow Hive product design, Exploding Kittensgame cards, and so on. In Indonesia, most of the crowd funding model applied is the capital donations. Some examples of successful projects funded are the production of some movies such as "Ketika Mas Gagah Pergi", "Efek Rumah Kaca", "Rumah Harapan", "Momentum Pergerakan Save Master", and so on.

Apparently, SMEs in Indonesia has great potential to be developed through model of crowd funding 
as proven by the presence of foreign institutions that operate such model. For example, Crowdo (financial technology company of Singapore) has announced the launching of the crowd funding platform loan for start-up business and small and medium enterprises (SMEs) in Indonesia. Crowdo is targetting of working capital loans providing to business activities that are not served by conventional financial system yet.

This fact proves that crowd funding is a model that can be applied to improve the financial inclusion of SMEs. Based on this fact too, this study was conducted to create a financing model of for SMEs through crowd funding by proposing questions such as whether the crowd funding financing models appropriate to finance SMEs activities.

\section{METHODS}

Qualitative method was applied in this study to find a crowd funding business model for SMEs. The samples in this study were not used to infer the characteristics of the population, but they were used as respondents for modeling. The number of samples selected were 22 people consisting of 10 academicians, 3 crowd funding managers, 5 owners of SMEs, and 4 investors.

The data used were primary data obtained from the opinion of the respondents. The data collection was done during 4 months (April 2016 - July 2016) through interviews to get feedback on what they needed to create models from the perspective of academicians, crowd funding managers, SME owners and investors (crowdfunder).

Interviews were conducted to discuss the model of crowd funding (donation, reward, pre-purchase, lending, equity) which were most suitable for SMEs and investors, an element in the business model canvas (Customer Segment, Value Proposition, Channel, Customer Relationship, Revenue Stream, Key Resourcess, Key Activities, Key Partnership and Cost Structure) for the manager of crowd funding, the flow of financial transactions and regulation.

\section{RESULTS}

Based on interviews with the respondents, it was agreed that an appropriate and equitable model of crowd funding for SMEs was profit sharing principles-based investment models. Profit sharing principle is same with mudharabah in sharia finance. The principle of profit sharing with mudharabah was applied in this model because the contract was one of a tijarah contract. Tijarah contract is a contract approvedto get financial profit but it is still done by sticking to the principles of sharia. Mudharabah is the fairer and precise contract if it is compared with conventional contract because in a conventional contract, the owners of capital get benefit certainly even though the recipient of capital get loss.

Mudharabah is a partnership contract of profit sharing, trust investment or financing trust between the capital owner (sahib al-mal) with employer or entrepreneur as partner (mudharib). Capital provided by the owner will be managed by entrepreneur with no guarantee that he will get profit or benefit. If the profit is obtained as the excess of capital, both parties will share the profits as agreed earlier. However, if the loss occurs, the owners of capital will bear the loss, too (Hidayat, 2011).

\section{DISCUSSIONS}

Slightly different from the crowd funding actors as Agrawal, Catalini, and Goldfarb (2013) introduced (creators, funders and platforms), crowd funding actors which were raised from this study consisted of three main actors, namely SMEs as those in need of capital, crowd funders provider of capital, and the operators of crowd funding as a party to bring together and facilitate business cooperation among SMEs with crowd funders. Another component is website that supports the crowd funding platform and a bank as payment gateway.

\section{Figure 1. Crowd Funding Financing Model}

The working mechanism of the model are as explained below :

1. SMEs that needs capital for its business must register (campaign) through crowdfunding website.

2. Crowd funding operator is selecting to determine its eligibility to be funded and add the selected in the website.

3. Then, crowd funder candidate see the website to select and define SMEs that they want to fund.

4. Later, crowd funder is transferring fund through the bank designated.

5. Crowd funder is confirming to the operator that the remittances has been done. 
6. Bank is confirming to the operator that the remittances from the crowd funder has been received.

7. Afterward, operator is authorizing the bank to transfer the money to SMEs.

8. Bank is transferring the money to SMEs.

9. A SME is utilizing the fund to finance the project handled.

10. If the project can generate the profit, the SMEs gets profit that is shared based on the agreement.

11. Crowd funder is getting profit sharing from capital gains and return of initial capital that is transferred through the bank.

12. Bank is transferring profit sharing and return of initial capital to the crowd funder.

In this model, there are nine elements of the Business Model Canvas that describe how an organization creates, delivers and captures the value. Business Model Canvas is a business model that describes the reason of how an organization creates, delivers and captures value (Osterwalder \& Pigneur, 2010). This model has nine elements of Customer Segments, Value Proposition, Channel, Customer Relationship, Revenue Stream, Resourcess Key, Key Activities, Key Partnership and Cost Structure.

Some explanations for nine elements in crowd funding business models are described below:

\section{Figure 2. Business Model Canvas of Crowd Funding}

- Customer Segment.

Customer Segment in this model are SMEs and funders (in this case is crowd funders). SMEs are selected customer who has a chance to get fund injection from the crowd funders. Crowd funders itself are divided into individuals, organizations and institutions fund owners.

- Value Preposition.

Value given to the customer is a business financing for SMEs and profit sharing for the crowd funders.

- Channels.

The channels that are used to search for or associated with the customer are social networks (Facebook, Twitter, or
Path), organization/ business community, and higher education institutions that have fostered villages or business group.

- Customer Relationship.

To build relationships with customers, it can be done by presenting a report of the assessment/ selection of candidates for SMEs to be funded, the source and amount of funds collected report, and use of funds report.

- Revenue Stream.

Revenues from the business is derived from administrative fees, SMEs profit sharing, paid advertising (paid per click/ paid per impression) and advertising revenue from sponsors displayed on the crowd funding website.

- Key Resources.

Crowd funding platform in the form of a website is the key resources in this model. In the website, there is a list of some SMEs that are eligible to be funded where the crowd funder is free to choose SMEs that want to be funded, the list of completed projects, lists of project progress report, and financial accountability report.

- Key Activities.

Key activities of this model is the selection of SMEs that are eligible to be funded.

- Key Partnership.

Key partnership is conducted by forming partnerships with other parties in order to optimize the services that consists of banks as the means of distribution and storage of funds, higher education institution as consultants/ associates for SMEs and business organizations/ business community as sources of information of existence of SMEs. These three components are important because they can beutilized to empower SMEs. Therefore, the role of academicians, businessmen, and community are needed (Ghazali \& Martini, 2012).

- Cost Structure.

The most important cost component in this business are SMEs selection/ screening cost, website domain and 
hosting cost, internet access cost, auditor fees, and, employee salaries.

\section{CONCLUSIONS AND SUGGESTIONS}

Crowd funding is one applicable solution to solve the problem of financial inclusion. Crowd funding model to be considered as the appropriate and fair for SMEs is a profit sharing based investment models for through mudharabah in shariate finance. The capital provided by investor (crowd funder) will be managed by business partner without guarantee of profit getting. When the profit is gotten, poth parties will share it based on agreement. However, when the business pursued by partners gets loss, the investor will bear all the loss, too.

The innovation emerged from implementation of the model is gong to be able to provide a positive impact for SMEs and investors, which in turn will give an impact upon public. Some these impacts are providing investors (crowd funders) alternative investment channel, investment diversification way for investors to allocate their funds in some SMEs, eliminating the constraints faced by SMEs to obtain financing access from conventional financial institutions, and beginner businessmen (start up businessmen) can find access to capital despite having no enough previous track record. It is something that can not be found from conventional financial institutions.

SMEs will no longer make the capital factor as a matter so that they will prioritize business development. They are trying to give good performance and reputation to get wider financing access and there will be more SMEs that are successfully empowered to make the other people interested to start and grow business. This condition is very condusife to reduce unemployment and to raise the level of welfare.

This model does not need much wares. Thus, it is very replicable. As shown in the Business Model Canvas, key resources in this model is the website as a platform for crowdfunding. Therefore, this business model can be run via internet without physical office. The underlying infrastructure required is internet access and crowd funding website. However, crowd funding as a relatively new financing platform still needs clear and condusive regulations because until the present, there is no the regulations governing crowdfunding in Indonesia yet.

\section{REFERENCE}

Agrawal, A. K., Catalini, C., \& Goldfarb, A. (2013). Some simple economics of crowdfunding: National Bureau of Economic Research.

Bansal, A. (2012). Profitable Model for Financial Inclusion. Global Journal of Management and Research October-December, 1.

Cole, S. A., Sampson, T. A., \& Zia, B. H. (2009). Financial literacy, financial decisions, and the demand for financial services: evidence from India and Indonesia: Harvard Business School.

DEFINIT. (2013). Developing an Indonesian Financial Literacy Index DEFINIT, Support for Economic Analysis Development in Indonesia (SEADI), and Otoritas Jasa Keuangan (OJK).

Ghazali, A., \& Martini, L. (2012). Bandung as Service City in Indonesia: Role of Academician, Business, and Community. Procedia - Social and Behavioral Sciences, 52, 317-324. doi: http://dx.doi.org/10.1016/j.sbspro.2012.09. $\underline{469}$

Gwalani, H., \& Parkhi, S. (2014). Financial Inclusion - Building a Success Model in the Indian Context. Procedia - Social and Behavioral Sciences, 133, 372-378. doi: http://dx.doi.org/10.1016/j.sbspro.2014.04. $\underline{203}$

Harrison, R. (2013). Crowdfunding and the revitalisation of the early stage risk capital market: catalyst or chimera? Venture Capital, 15(4), 283-287.

Hidajat, T. (2015). An Analysis of Financial Literacy and Household Saving among Fishermen in Indonesia. Mediterranean Journal of Social Sciences, 6(5 S5), 216. doi: $10.5901 / \mathrm{mjss} .2015 . v 6 \mathrm{n} 5 \mathrm{~s} 5 \mathrm{p} 216$

Hidayat, T. (2011). Buku pintar investasi syariah: Mediakita.

Langley, P. (2016). Crowdfunding in the United Kingdom: A Cultural Economy. Economic Geography, 92(3), 301-321. doi: 10.1080/00130095.2015.1133233

Osterwalder, A., \& Pigneur, Y. (2010). Business model generation: a handbook for visionaries, game changers, and challengers: John Wiley \& Sons.

Prasetyo, P. E. (2008). Peran Usaha Mikro Kecil dan Menengah (UMKM) dalam Kebijakan 
Penanggulangan Kemiskinan dan

Pengangguran. AKMENIKA UPY, 2.

Prive, T. (2012). Top 10 Benefits Of

Crowdfunding. Retrieved July 22, 2016,

from

http://www.forbes.com/sites/tanyaprive/20

12/10/12/top-10-benefits-of-

crowdfunding-2/\#32e75b0371a8

Rillo, A. D. (2014). Overview of Financial

Inclusion in Asia. Financial Inclusion in

Asia : Country Surveys: Asian

Development Bank Institute.

Roig Hernando, J. (2016). Crowdfunding: The collaborative economy for channelling institutional and household savings.

Research in International Business and

Finance, 38, 326-337. doi: http://dx.doi.org/10.1016/j.ribaf.2016.03.0 $\underline{04}$

Rosengard, J. K., \& Prasetyantoko, A. (2011). If the banks are doing so well, why can't I get a loan? Regulatory constraints to financial inclusion in Indonesia. Asian Economic Policy Review, 6(2), 273-296.

Shaban, M., Duygun, M., Anwar, M., \& Akbar, B. (2014). Diversification and banks' willingness to lend to small businesses: Evidence from Islamic and conventional banks in Indonesia. Journal of Economic Behavior \& Organization, 103, Supplement, S39-S55. doi: http://dx.doi.org/10.1016/j.jebo.2014.03.0 $\underline{21}$

Tomczak, A., \& Brem, A. (2013). A conceptualized investment model of crowdfunding. Venture Capital, 15(4), 335-359. doi: 10.1080/13691066.2013.847614

Vasileiadou, E., Huijben, J. C. C. M., \& Raven, R. P. J. M. (2016). Three is a crowd?

Exploring the potential of crowdfunding for renewable energy in the Netherlands.
Journal of Cleaner Production, 128, 142155. doi:

http://dx.doi.org/10.1016/j.jclepro.2015.06 .028

Vulkan, N., Åstebro, T., \& Sierra, M. F. (2016).

Equity crowdfunding: A new phenomena. Journal of Business Venturing Insights, 5, 37-49. doi:

http://dx.doi.org/10.1016/j.jbvi.2016.02.00 $\underline{1}$ 
Figure 1. Crowd Funding Financing Model

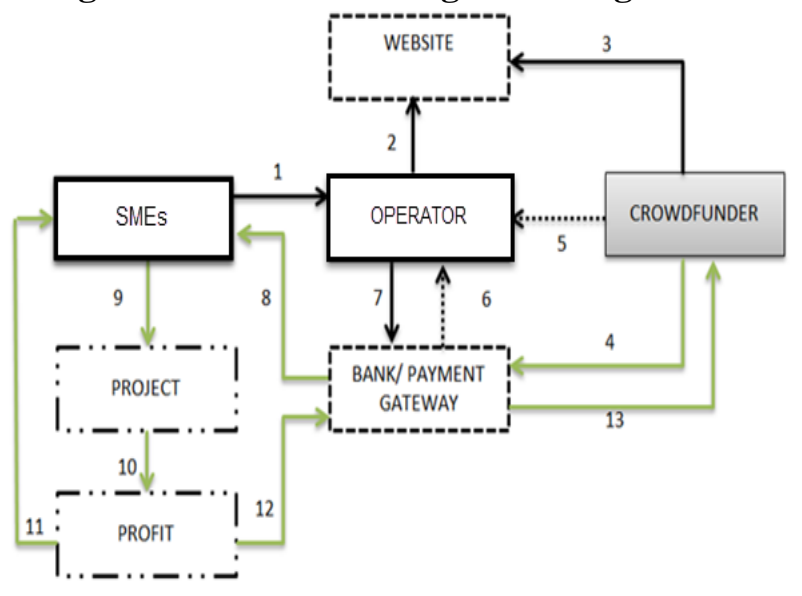

Figure 2. Business Model Canvas of Crowd Funding

\begin{tabular}{|c|c|c|c|c|}
\hline \multirow[t]{2}{*}{$\begin{array}{l}\text { Key Partners } \\
\text { - Banks. } \\
\text { - Higher education } \\
\text { institution, } \\
\text { - Business } \\
\text { community. }\end{array}$} & $\begin{array}{l}\text { Key Activities } \\
\text { - Selecting SMEs. }\end{array}$ & \multirow[t]{2}{*}{$\begin{array}{l}\text { Value Proposition } \\
\text { - Business } \\
\text { financing. } \\
\text { - Profit sharing. }\end{array}$} & $\begin{array}{l}\text { Customer } \\
\text { Relationships } \\
\text { - Assessment// } \\
\text { selection of } \\
\text { candidates } \\
\text { reports. } \\
\text { - Source and use of } \\
\text { funds reports. }\end{array}$ & \multirow[t]{2}{*}{$\begin{array}{l}\text { Customer Segments } \\
\text { - SMEs. } \\
\text { - Funders. }\end{array}$} \\
\hline & $\begin{array}{l}\text { Key Resources } \\
\text { - Platform } \\
\text { (website). }\end{array}$ & & $\begin{array}{l}\text { Channels } \\
\text { - Social networks. } \\
\text { - Organization/ } \\
\text { business } \\
\text { community. } \\
\text { - Higher education } \\
\text { institutions. }\end{array}$ & \\
\hline \multicolumn{2}{|c|}{$\begin{array}{l}\text { Cost Structure } \\
\text { - Screening cost. } \\
\text { - Domain and hosting cost. } \\
\text { - Internet access cost. } \\
\text { - Auditor fees. } \\
\text { - Employee salaries. }\end{array}$} & \multicolumn{3}{|c|}{$\begin{array}{l}\text { Revenue Streams } \\
\text { - Administrative fees. } \\
\text { - AMEs profit sharing. } \\
\text { - Advertising revenue. }\end{array}$} \\
\hline
\end{tabular}

